\title{
Assessment of Vegetative Growth Characteristics and Yield of Different Types of Cluster Bearing Ridge Gourd (Luffa acutangula Roxb.)
}

\author{
Priyanka Baruah, Nayanmoni Buragohain*, B. P. Gautam, \\ D. N. Hazarika, H. Chudhury and M. K. Kalita \\ Biswanath College of Agriculture, Assam Agricultural University, \\ Biswanath Chariali-784176, Assam, India \\ *Corresponding author
}

\section{A B S T R A C T}

\section{Keywords}

Ridge gourd, Cluster bearing, Growth, Yield

Article Info

Accepted: 15 November 2019 Available Online: 10 December 2019
A field experiment was carried out during kharif season of 2018 to assess the growth and yield of different types of cluster bearing ridge gourd. The experiment comprised of five different types of cluster bearing ridge gourd viz. type -1,locally known as 'Satpati Long' $\left(\mathrm{T}_{1}\right)$, type -2 , locally known as 'Satpati Small' $\left(\mathrm{T}_{2}\right)$, type-3, locally known as 'Mou Jika' $\left(\mathrm{T}_{3}\right)$, type- 4 , locally known as 'Thupi Jika' $\left(\mathrm{T}_{4}\right)$ and type -5 , locally known as 'Thupi Dighal' $\left(\mathrm{T}_{5}\right)$ and laid out in randomized block design. The experimental results revealed that maximum vine length at 90 and 120 days after sowing $(440.25 \mathrm{~cm}$ and $687.25 \mathrm{~cm})$, intermodal length $(13.54 \mathrm{~cm})$,number of primary branches $(7.25)$, number of nodes per vine (50.75), number of functional leaves per vine at 90, 105 and 120 days after sowing $(216.50,436.50$ and 187.00$)$, fruit circumference $(14.03 \mathrm{~cm})$, fruit volume $(174.50 \mathrm{cc})$,fruit fresh weight(154.62 g/fruit), fruit yield /vine $(7.28 \mathrm{~kg})$, fruit yield per hectare $(12.15 \mathrm{t} / \mathrm{ha})$ and number of seeds per fruit(159.50) were recorded by $\mathrm{T}_{4}$. The maximum area of leaf $\left(106.54 \mathrm{~cm}^{2}\right.$ and $\left.107.05 \mathrm{~cm}^{2}\right)$, leaf area per vine $\left(2.22 \mathrm{~m}^{2}\right.$ and $\left.1.89 \mathrm{~m}^{2}\right)$ at 90 and 120 days after sowing and fruit length $(21.23 \mathrm{~cm})$ were exhibited by $\mathrm{T}_{5}$. On the other hand maximum number of fruits per cluster (6.25) was recorded in $T_{1}$ but highest number of fruit clusters per vine (43.25) and number of fruits per vine (181.50) were produced in $T_{2}$. The shortest days for appearance of male flower (34.75) at node number 4.5 and female flower (40.50) at $7^{\text {th }}$ node number with lower male: female ratio $(19.50: 1)$ was recorded in $\mathrm{T}_{3}$ between $\mathrm{T}_{3}$ andT $\mathrm{T}_{5}$ where both male and female flowers were borne. But $\mathrm{T}_{4}$ recorded the shortest days for flowering (38.75) and duration for first picking (67.25) among $T_{1}, T_{2}$ and $\mathrm{T}_{4}$ where only hermaphrodite flowers were borne.

\section{Introduction}

Ridge gourd (Luffa acutangula Roxb.) is one of the most important annual vegetable crops preferred by almost all people for its taste, flavour, nutritional value and health benefits. It belong to family Cucurbitaceae with diploid chromosome number $(2 \mathrm{n}=26)$ and is cross pollinated crop. Ridge gourd is native to India (Muthaiah et al., 2017) and grown throughout 
the year in all the tropical regions especially in Asian and African countries. It is one of the predominant summer vegetables grown in India in summer and kharif seasons. In North East India including Assam too there is great demand of this vegetable and it is locally known as 'Jika' in Assam.

The fruits of Ridge gourd are used as vegetables and are harvested at different stages of maturity depending upon market demand. It is known as "vegetables of diet food' because of its high moisture, minerals, vitamins and carotenoid content and low calorific value. It is an excellent blood purifier, a cure for jaundice, healthy digestion and beneficial for aiding weight loss, antiinflammatory, antidiabetic, anticancerous, antioxidant, skin care and proper functioning of excretory system.

Generally ridge gourds are monoecious in nature. But ridge gourd has an ancestral form 'Satputia' found in Bihar which is hermaphrodite and is given a separate taxonomy status as Luffa hermaphrodita (Singh and Bhandari,1963). Monoecious ridge gourd is late in maturity and produces large size fruit with less production. Whereas, hermaphrodite form is early in maturity 'and produces large number of small size fruits in clusters. A cluster bearing variety, 'Swarna Sawani' (Satputia) of ridge gourd was developed through pure line selection from a local collection which was recommended for cultivation in Jharkhand, Bihar and adjoining areas (Anon., 2013).

In Assam, some local predominant types of ridge gourd of different shapes and sizes are successfully grown in homestead gardens and are also marketed, which bear fruits in clusters with quite good yield and quality. However, these cluster bearing ridge gourd types are not getting due weightage from the researchers and commercial vegetable growers of other regions of the state. As such, their full potential is not explored yet due to lack of information and they are concentrated on few pockets of the state. The available information which explains the growth and yield of different cluster bearing ridge gourd in Assam condition is needed to explore their full potential so as to enrich nutrient in our food by adding these in our diet. Since no systematic studies have been done on these aspect an experiment was planned to study the growth and yield of locally available cluster type of ridge gourd and to screen out the most suitable type based on yield performance.

\section{Materials and Methods}

To assess the vegetative growth and yield of different types of cluster bearing ridge gourd an experiment was laid out at the Instructional cum Research Farm, Department of Horticulture, Biswnath College of Agriculture, Assam Agricultural University, Biswanath Chariali during February to August,2018. The soil of the experimental plot was well drained, sandy loam and acidic (5.36) with good water holding capacity. The experimental field was thoroughly ploughed and a recommended dose of10 $\mathrm{kg} \mathrm{N}$ (as Urea), $30 \mathrm{~kg} \mathrm{P}_{2} \mathrm{O}_{5}$ (as SSP) and $30 \mathrm{~kg} \mathrm{~K}_{2} \mathrm{O}$ (as MOP) along with FYM@ $10 \mathrm{t}$ per hectare were applied at the time of final land preparation. After 35 days of sowing another $10 \mathrm{~kg}$ of $\mathrm{N}$ was applied around the base of the vine by ring method. The experiment was comprised of five different types of cluster bearing ridge gourd viz. type 1, locally known as 'Satpati Long'( $\left.\mathrm{T}_{1}\right)$, type 2,locally known as 'Satpati Small' $\left(\mathrm{T}_{2}\right)$, type-3, locally known as 'Mou Jika' $\left(\mathrm{T}_{3}\right)$, type-4, locally known as 'Thupi Jika' $\left(\mathrm{T}_{4}\right)$ and type 5, locally known as 'Thupi Dighal' $\left(\mathrm{T}_{5}\right)$ which was laid out in randomized block design with four replications. The seeds were collected from different locations of Assam like $T_{1}$ from Jorhat, $\mathrm{T}_{2}$ from Golaghat district and $\mathrm{T}_{3}, \mathrm{~T}_{4}$ and $\mathrm{T}_{5}$ from Biswanath district. The seeds were 
sown in pits of $45 \mathrm{~cm} \mathrm{x} 45 \mathrm{~cm} \mathrm{x} 45 \mathrm{~cm}$ size at a spacing of $2 \mathrm{~m} \times 3 \mathrm{~m}$. The plants were trained in bower system of training. All the management practices including weeding, irrigation, plant protection were done whenever it was necessary. The fruits were harvested at tender green stage before the fiber development when they attained marketable size. The observations on vine length $(\mathrm{cm})$, number of primary branches per vine, number of nodes per vine, intermodal length of vine $(\mathrm{cm})$, number of functional leaves per vine, area of a leaf $\left(\mathrm{cm}^{2}\right)$, leaf area per vine $\left(\mathrm{m}^{2}\right)$, days to appearance of first male, female and hermaphrodite flower, node number at which first male, female and hermaphrodite flower appears, days to first picking from sowing, fruit length $(\mathrm{cm})$, fruit circumference $(\mathrm{cm})$, fruit volume (cc), fruit weight $(\mathrm{g})$, number of seeds per fruit, number of fruits per cluster, number of fruit cluster per vine, number of fruits per vine, total yield per vine $(\mathrm{kg})$ and yield per plot $(\mathrm{kg})$ were recorded from three randomly selected plants of each replication.

The vine length was measured in centimeters from the base of the plant to the apex of the main vine with the help of measuring tape at 90 and 120 days after sowing (DAS). Total number of primary branches of individual plant was counted at the stage of final harvesting. The number of nodes in the main vine was counted from the base to the tip of the plant at the time of final harvest. The length of internode was measured with the help of measuring tape between the $4^{\text {th }}$ and $5^{\text {th }}$ node from the apex of the vine at final harvest. All the leaves where minimum $2 / 3^{\text {rd }}$ portion of leaf lamina remained green were considered as functional leaves. The number of functional leaves present in three primary branches per vine was counted and then the average numbers of leaf per primary branches were calculated out at 90,105 and 120 days after sowing (DAS). Leaf area was measured with the help of Portable Leaf Area Meter,
Model:CI-203 at 90 and 120DAS.Node number at which first male, female and hermaphrodite flower appeared were counted from ground level. The number of days from sowing to fruit maturity was recorded in all tagged vines of each plot and the average was calculated for each replication to count the days to first picking. Randomly selected five fresh fruits of all tagged plants in each treatment were measured from the base of the stalk to the tip of fruit using a scale and average was calculated. Circumference was measured for five randomly selected fruits from each sampling plants at base, middle and apex portion of the fruit with the help of measuring tape and average was calculated. Same five fruits were used to measure the fruit weight and were weighed with the help of electronic balance, the mean weight of fruits was calculated and expressed in gram. Volume was measured by using water displacement method. For this purpose, fruits were dipped in a full filled jar of water and the water displaced by the fruits was collected and measured by graduated glass jar and average volume of fruit was calculated. To count the seeds ten matured fruits were randomly selected and allowed to dry on the plant itself. After that the number of seeds were counted by opening the fruit longitudinally and then averaged to obtain the number of seeds per fruit. Total number of clusters per vine was counted on plants and averages were computed. Total number of fruits per cluster was counted from randomly selected five clusters on all the three tagged vine and average was calculated. The total number of fruits per vine was calculated by multiplying the number of fruit cluster per vine with the number of fruits per cluster. The total harvested fruit weight from the three tagged vines were recorded considering all harvests and then the average fruit yield per vine was computed for getting total yield per vine and expressed in $\mathrm{kg}$. The yield of fruits per plot was calculated by multiplying fruit yield per 
vine with total number of vines per plot and expresses in $\mathrm{kg}$. The yield per hectare was estimated by multiplying the average fruit yield per plot of each treatment with the total number of plots that can be accommodated per hectare and was expressed in tonne per hectare(t/ha).

\section{Statistical analysis}

The observations recorded during field experiment were subjected to the statistical analysis of variance by Randomized Block Design (RBD). Significance and nonsignificance of the variance due to different treatments were determined by calculating the respective ' $F$ ' value as the method described by Panse and Sukhatme (1985).

\section{Results and Discussion}

Data (Table 1) revealed that maximum vine length $(440.25$ and $687.25 \mathrm{~cm})$ at 90 DAS and 120 DAS, number of primary branches per vine (7.25), number of nodes per vine (50.75), intermodal length(13.55)and number of functional leaves per vine at 90 DAS, 105DAS and 120 DAS $(216.50,436.50$ and 187.00) were recorded in $\mathrm{T}_{4}$ (type-4, locally known as 'Thupi Jika'). The best performance by $\mathrm{T}_{4}$ may be due to its capacity to produce more biomass with the same available inputs but with an efficient internal mechanism acquired because of its genetic make up. Higher vine length might have led to production of more number of branches and bear more number of leaves. These findings were in conformity with the works of Kadam and Kale (1987), Abusaleha and Dutta (1990), Singh et al., (2013) and Reddy et al., (2013) who also found significant variation in morphological parameters in different cultivars of ridge gourd and bitter gourd. More vine length at 120 DAS in all the treatment might be due to the fact that plants got extra 30 days to absorb more nutrients to carry out metabolic activities which resulted in more production and assimilation of biomass. This was in close confirmation of the earlier findings of Yoo et al., (2003). The higher production of functional leaves at 105 DAS and reduction of functional leaves at 120 DAS might be due to the fact that onset of senescence process take place of the plants after 105 DAS. Significant variation among different types of ridge gourd was observed in respect to individual leaf area and leaf area per vine. Type -5 , locally known as 'Thupi Dighal' $\left(\mathrm{T}_{5}\right)$ produced maximum individual leaf area (106.54 and $\left.107.05 \mathrm{~cm}^{2}\right)$ and leaf area per vine $\left(2.22\right.$ and $\left.1.89 \mathrm{~m}^{2}\right)$ at 90 DAS and 120 DAS and minimum was recorded in type -2, locally known as 'Satpati Small' $\left(\mathrm{T}_{2}\right)$. This might be attributed to the genetic configuration of $\mathrm{T}_{5}$ plants. Karthick et al., (2017a) found similar results at 60 DAS in Pusa Nasdar variety of ridge gourd among six varieties tested.

Among the five different types, $\mathrm{T}_{3}$ and $\mathrm{T}_{5}$ produced male and female flower while $T_{1}, T_{2}$ and $\mathrm{T}_{4}$ produced only hermaphrodite flowers (Table 2). Therefore no statistical analysis could be done. However $\mathrm{T}_{4}$ was found superior in terms of shortest days taken for first production of hermaphrodite flower (38.75), for first picking of fruits (67.25) and produced first flower on its lowest node (5.25). This might be the result of maintaining superiority in the morpho-physiological characters by $\mathrm{T}_{4}$.

The different types showed a significant variation in different fruit characters like fruit length, fruit circumference, fruit volume, fruit weight, number of seeds per fruit (Table 3), number of fruits per cluster, number of fruit cluster per vine, number of fruits per vine, fruit yield per vine and fruit yield per hectare (Table 4). 
Table.1 Vine length, number of primary branch/vine at harvest, number of nodes/vine at harvest, intermodal length at harvest ,number of functional leaves/vine, individual leaf area and leaf area

/vine of different cluster bearing ridge gourd

\begin{tabular}{|c|c|c|c|c|c|c|c|c|c|c|c|c|}
\hline \multirow[t]{2}{*}{$\begin{array}{l}\text { Treat } \\
\text { ment }\end{array}$} & \multicolumn{2}{|c|}{$\begin{array}{c}\text { Vine } \\
\text { length }(\mathrm{cm})\end{array}$} & \multirow{2}{*}{$\begin{array}{c}\text { Primary } \\
\text { branch/ } \\
\text { vine } \\
\text { (no.) }\end{array}$} & \multirow{2}{*}{$\begin{array}{c}\text { nodes/ } \\
\text { vine } \\
\text { (no.) }\end{array}$} & \multirow{2}{*}{$\begin{array}{c}\text { Inter- } \\
\text { nodal } \\
\text { length } \\
(\mathrm{cm})\end{array}$} & \multicolumn{3}{|c|}{$\begin{array}{c}\text { Functional leaves/vine } \\
\text { (no.) }\end{array}$} & \multicolumn{2}{|c|}{$\begin{array}{l}\text { Area of a leaf } \\
\left(\mathrm{cm}^{2)}\right.\end{array}$} & \multicolumn{2}{|c|}{$\begin{array}{l}\text { Leaf area } \\
/ \text { vine }\left(\mathbf{m}^{2}\right)\end{array}$} \\
\hline & $\begin{array}{c}90 \\
\text { DAS* }\end{array}$ & $\begin{array}{c}120 \\
\text { DAS }\end{array}$ & & & & $\begin{array}{c}90 \\
\text { DAS }\end{array}$ & $\begin{array}{c}105 \\
\text { DAS }\end{array}$ & $\begin{array}{c}120 \\
\text { DAS }\end{array}$ & $\begin{array}{c}90 \\
\text { DAS }\end{array}$ & $\begin{array}{c}120 \\
\text { DAS }\end{array}$ & $\begin{array}{c}90 \\
\text { DAS }\end{array}$ & $\begin{array}{c}120 \\
\text { DAS }\end{array}$ \\
\hline $\mathbf{T}_{1}$ & 386.75 & $\begin{array}{c}549.5 \\
0\end{array}$ & 5.25 & 44.50 & 12.55 & 168.00 & 388.25 & 131.75 & 80.27 & 80.85 & 1.35 & 1.07 \\
\hline $\mathbf{T}_{2}$ & 341.75 & $\begin{array}{c}530.0 \\
0\end{array}$ & & & 11.75 & & 382.25 & 128.75 & 74.10 & 74.78 & 1.20 & 0.96 \\
\hline $\mathbf{T}_{\mathbf{3}}$ & 396.00 & $\begin{array}{c}574.0 \\
0\end{array}$ & & & 12.65 & 195.75 & 415.75 & 164.50 & 81.41 & 82.16 & 1.59 & 1.35 \\
\hline $\mathbf{T}_{4}$ & 440.25 & $\begin{array}{c}687.2 \\
5\end{array}$ & & 50.75 & 13.55 & 216.50 & 436.50 & 187.00 & 97.32 & 98.50 & 2.11 & 1.84 \\
\hline $\mathbf{T}_{5}$ & 407.00 & $\begin{array}{c}614.5 \\
0\end{array}$ & & 46.25 & 13.35 & 208.50 & 429.50 & 176.75 & 106.54 & 107.05 & 2.22 & 1.89 \\
\hline $\begin{array}{l}\text { CD } \\
(\mathbf{0 . 0 5})\end{array}$ & 0.87 & 1.16 & 0.99 & 0.74 & 0.16 & 1.07 & 1.22 & 1.42 & 0.72 & 0.53 & 0.01 & 0.02 \\
\hline
\end{tabular}

*Days after sowing

Table.2 Days to first appearance of male, female and hermaphrodite flower, node number at which first male, female and hermaphrodite flower appeared and ratio of male: female flower of different cluster bearing ridge gourd

\begin{tabular}{|c|c|c|c|c|c|c|c|c|}
\hline \multirow[t]{2}{*}{ Treatment } & \multicolumn{3}{|c|}{ Days to first appearance of } & \multicolumn{3}{|c|}{ Node number at which first } & \multirow[b]{2}{*}{$\begin{array}{c}\text { Ratio } \\
\text { of } \\
\text { male: } \\
\text { female } \\
\text { flower }\end{array}$} & \multirow[b]{2}{*}{$\begin{array}{c}\text { Days to } \\
\text { first } \\
\text { picking } \\
\text { from } \\
\text { sowing }\end{array}$} \\
\hline & $\begin{array}{l}\text { Male } \\
\text { flower }\end{array}$ & $\begin{array}{l}\text { Female } \\
\text { flower }\end{array}$ & $\begin{array}{l}\text { Hermaphrodite } \\
\text { flower }\end{array}$ & $\begin{array}{c}\text { Male } \\
\text { flower } \\
\text { appeared }\end{array}$ & $\begin{array}{l}\text { Female } \\
\text { flower } \\
\text { appeared }\end{array}$ & $\begin{array}{c}\text { Hermaphrodite } \\
\text { flower } \\
\text { appeared }\end{array}$ & & \\
\hline $\mathbf{T}_{1}$ & 0 & 0 & 43.50 & 0 & 0 & 5.75 & 0 & 72.25 \\
\hline $\mathbf{T}_{2}$ & 0 & 0 & 41.20 & 0 & 0 & 5.50 & 0 & 70.75 \\
\hline $\mathbf{T}_{3}$ & 34.75 & 40.50 & 0 & 4.5 & 7.00 & 0 & 19.5:1 & 69.00 \\
\hline $\mathbf{T}_{4}$ & 0 & 0 & 38.75 & 0 & 0 & 5.25 & 0 & 67.25 \\
\hline $\mathbf{T}_{5}$ & 39.75 & 46.25 & 0 & 5.75 & 8.75 & 0 & 38.25 & 75.00 \\
\hline \multicolumn{8}{|c|}{$\mathrm{CD}(\mathbf{0 . 0 5})$} & 0.95 \\
\hline
\end{tabular}


Table.3 Fruit length, fruit circumference, fruit volume, fruit weight and number of seeds per fruit of different cluster bearing ridge gourd

\begin{tabular}{|c|c|c|c|c|c|}
\hline $\begin{array}{c}\text { Treatmen } \\
\mathbf{t}\end{array}$ & $\begin{array}{c}\text { Fruit length } \\
(\mathbf{c m})\end{array}$ & $\begin{array}{c}\text { Fruit circumference } \\
(\mathbf{c m})\end{array}$ & $\begin{array}{c}\text { Fruit } \\
\text { volume } \\
(\mathbf{c c})\end{array}$ & $\begin{array}{c}\text { Fruit weight } \\
(\mathbf{g})\end{array}$ & $\begin{array}{c}\text { Number of } \\
\text { seeds / fruit }\end{array}$ \\
\hline $\mathbf{T}_{\mathbf{1}}$ & 11.87 & 11.78 & 47.07 & 48.25 & 80.75 \\
\hline $\mathbf{T}_{\mathbf{2}}$ & 8.00 & 12.18 & 36.35 & 34.13 & 67.75 \\
\hline $\mathbf{T}_{\mathbf{3}}$ & 13.77 & 12.44 & 70.53 & 76.65 & 95.50 \\
\hline $\mathbf{T}_{\mathbf{4}}$ & 20.37 & 14.03 & 174.50 & 154.62 & 159.50 \\
\hline $\mathbf{T}_{\mathbf{5}}$ & 21.23 & 11.64 & 137.96 & 108.86 & 150.75 \\
\hline $\mathbf{C D}(\mathbf{0 . 0 5})$ & 0.17 & 0.04 & 0.80 & 0.12 & 1.04 \\
\hline
\end{tabular}

Table.4 Number of fruits per cluster, Number of fruit clusters per vine, Number of fruits per vine, fruit yield per vine and fruit yield per hectare of different cluster bearing ridge gourd

\begin{tabular}{|c|c|c|c|c|c|}
\hline Treatment & $\begin{array}{c}\text { Number of } \\
\text { fruits / } \\
\text { cluster }\end{array}$ & $\begin{array}{c}\text { Number of } \\
\text { fruit clusters } \\
\text { / vine }\end{array}$ & $\begin{array}{c}\text { Number of } \\
\text { fruits / } \\
\text { vine }\end{array}$ & $\begin{array}{c}\text { fruit yield / } \\
\text { vine } \\
\text { (kg/vine) }\end{array}$ & $\begin{array}{c}\text { fruit yield / } \\
\text { hectare } \\
\text { (t/ha) }\end{array}$ \\
\hline $\mathbf{T}_{\mathbf{1}}$ & 6.25 & 22.00 & 136.50 & 6.59 & 11.00 \\
\hline $\mathbf{T}_{\mathbf{2}}$ & 4.25 & 43.25 & 181.50 & 6.20 & 10.36 \\
\hline $\mathbf{T}_{\mathbf{3}}$ & 3.00 & 30.50 & 92.00 & 7.09 & 11.84 \\
\hline $\mathbf{T}_{\mathbf{4}}$ & 3.50 & 14.00 & 47.25 & 7.28 & 12.15 \\
\hline $\mathbf{T}_{\mathbf{5}}$ & 1.75 & 31.75 & 50.25 & 5.47 & 9.12 \\
\hline $\mathbf{C D}(\mathbf{0 . 0 5})$ & 0.55 & 8.68 & 0.87 & 0.02 & 0.03 \\
\hline
\end{tabular}

Maximum circumference $(14.03 \mathrm{~cm})$, volume $(174.50 \mathrm{cc})$, weight $(154.62 \mathrm{~g})$ and number of seeds per fruit (159.50) were recorded in $\mathrm{T}_{4}$ while fruit length (21.23) was maximum in $\mathrm{T}_{5}$. $\mathrm{T}_{2}$ (type -2, locally known as 'Satpati Small') recorded minimum fruit length $(8.00 \mathrm{~cm})$, volume $(36.35 \mathrm{cc})$, weight $(34.13 \mathrm{~g})$ and number of seeds per fruit(67.75) while the circumference $(11.64 \mathrm{~cm})$ was minimum in $T_{5}$. The higher leaf area recorded in $\mathrm{T}_{4}$ which also yielded heavier fruits that indicated a positive correlation between area of functional leaf, the site for production of photosynthates and the fruit yield per vine. Being the strongest sink, the seeds might pull more dry matter at faster rate to the seed thus helped to accumulate more dry matter in fruits that led to increase in size, volume and diameter of fruit. These observations were in close agreement with the findings of earlier worker Khule et al., (2011); Gowda (2012); Singh et al., (2016) and Buhroy et al., (2017) who reported higher chlorophyll content of leaf, relative water content, number of fruits per vine, fruit diameter, fruit volume and fruit weight that finally increased the fruit yield per vine. Maximum number of fruits per cluster (6.25) was observed in $T_{1}$ (type -1,locally known as 'Satpati Long') while significantly highest number of fruit clusters per vine (43.25) and fruits per vine (181.50) in $T_{2}$. The highest fruit yield per vine $(7.28 \mathrm{~kg})$ and per hectare $(12.15$ $t$ ) were recorded in $T_{4}$. Because of the better growth of $\mathrm{T}_{4}$ along with higher better physiological parameters might have led to generate better yield. As all the types were grown in similar environmental condition with similar cultural practices so it could be stated 
that the hereditary characters of the ridge gourd might be the superior controlling factor among others that determined the growth and yield parameters. These results were in conformity with the findings of Singh et al., (2002); Karthick et al., (2017b) and Rathore et al., (2017) who reported a wide range of variation among different types of ridge gourd in relation to yield parameters.

\section{References}

Abusaleha and Dutta,O.P.1990. Studies on variability, heritability and scope of improvement in Ridge gourd. $J$. Maharashtra. Agric. Univ., 15(3):333334

Anonymous.2013. Improved varieties of fruits and vegetables developed by ICAR RCER. Tech. Bull. no. R-42, P.17

Buhroy, S., Arumugam, T., Manivannan, N., Vethamoni, P.I. and Jeyakumar, P. 2017. Correlation and path analysis of drought tolerance traits on fruit yield in tomato (Solanum lycopersicum L.) under drought stress condition. Chem. Sci. Rev. Lett., 6(23): 1670-1676

Gowda, H. 2012. Genetic variability studies in ridge gourd. [Luffa acutangula (L.) Roxb.] Master of Science thesis submitted to University of Horticultural Sciences, Bagalkot, India.

Kadam, P.Y. and Kale, P.N.1987. Genetic variability in ribbed gourd (Luffa acutangula L.). J. Maharashtra. Agric. Univ., 12(2): 242-243

Karthick, K., Patel, G.S. and Jat, G.P. 2017a. Performance of ridge gourd (Luffa acutangula L.Roxb.) varieties and nature of cultivation on growth and flowering attributes. Int.J.Agric.Sci., 9(8): 3910-3912.

Karthick, K., Patel, G.S., Shanmugapriya, V. and Varsat, B.A. 2017b. Performance of ridge gourd (Luffa acutangula
L.Roxb.) varieties and nature of cultivation for yield and yield attributes. Int.J.Curr.Microbiol. App.Sci., 6(3):458-462

Khule, A.A., Tikka, S.B.S., Jadhav, D.J. and Kajale, D.B. 2011.Correlation and path coefficient analysis in sponge gourd. Int. J. Plant. Sci., 6(2): 277-279

Muthaiah, M.K., Gasti, V.D., Mallesh, S. and Nagaraju, K. 2017. Heterosis studies for earliness and yield related traits in ridge gourd. [Luffa acutangula (L.) Roxb.] Int.J.Curr.Microbiol.App.Sci., 6(6): 2656-2661.

Panse, V.G. and Sukhatme, P.V. 1985. Statistical methods for agricultural workers, $4^{\text {th }}$ Edn., ICAR, New Delhi.

Rathore, J.S., Collins, J.P., Singh, G., Rajawat, K.S. and Jat, B.L. 2017. Studies on genetic variability in ridge gourd [Luffa acutangula. L. (Roxb.)] genotypes in Allahabad agro-climatic condition. Int.J.Curr.Microbiol.App. Sci., 6(2): 317-338

Reddy, R.P., Reddy, V.S.K. and Padma, S.S.V. 2013. Performance of parents and hybrids for yield and yield attributing characters in ridge gourd (Luffa acutangula (Roxb.) L. Bioscan, 8(4): 1373-1377.

Singh, B., Singh, A.K. and Kumar, S.2013. Genetic divergence studies in bitter gourd (Momordica charantia L.) Acad. J.Plant.Sci., 6(2): 89-91

Singh, D. and Bhandari, M.M. 1963. The identity of an imperfectly known hermaphrodite Luffa, with a note on related species. Baileya, 11:132-141

Singh, P., Kurrey, V.K., Minz. R.R. and Moharana, D.P. 2016. Correlation coefficient analysis between fruit yield and qualitative traits of pointed gourd (Trichosanthes dioica Roxb.) in Chhattisgarh region. Ecoscan, 9:33-38.

Singh, R.P., Mohan, J. and Singh. D. 2002. Studies on genetic variability and 
heritability in ridge gourd. Agric. Sci. Dig., 22(4): 279-280

Yoo. S.D., Gree, D.H., Laing, W.A. and McManus, M.T. 2003. Changes in photosynthetic efficiency and carotenoid composition in leaves of white clover at different developmental stages. Plant Physiol. Biochem., 41(10): 887-893

\section{How to cite this article:}

Priyanka Baruah, Nayanmoni Buragohain, B. P. Gautam, D. N. Hazarika, H. Chudhury and Kalita, M. K. 2019. Assessment of Vegetative Growth Characteristics and Yield of Different Types of Cluster Bearing Ridge Gourd (Luffa acutangula Roxb.). Int.J.Curr.Microbiol.App.Sci. 8(12): 1964-1971. doi: https://doi.org/10.20546/ijcmas.2019.812.234 